\title{
PRACTICAL POINTS IN PUBLIC HEALTH ADMINISTRATION.*
}

BY J. F. J. SYKES, M.D.,

President of the Metropolitan Branch of the Incorporated Society of Medical Officers of Health; Medieal Officer of Health of St. Pancras.

Ат our last meeting I had the privilege of laying before you some points in Public Health Administration in reference to Powers of Entry, Drainage Bye-laws, Paving and Drainage of Stables, and Storage of Manure, in the form of a short paper which appeared in the August number of Public Health. ${ }^{\dagger}$

As to Powers of Entry.-It was pointed out that the powers of sanitary authorities with regard to sehools, especially elementary day-schools, are altogether inadequate. Instead of being less, these powers should be more extensive than those with regard to many other classes of premises. This Society would do well to consider this question seriously, and to direct the attention of Parliament to it, if found advisable. At the same time the questions of cleansing, overcrowding, and ventilation of such premises, in addition to watersupply, drainage, and disinfection, might be taken into consideration, and also how far it should be incumbent upon teachers to report to the medical officer of health all absences suspected to be caused by infectious diseases, including measles, whooping-cough, diarrhœea, mumps, chicken-pox, etc.

As to Drainage Bye-laws. - It was suggested that pressure should be put upon the London County Council to issue the long-promised bye-laws as soon as possible. It may now be added that a statutory interpretation should be obtained of the phrase "making of a drain" under the Metropolis Local Management Acts. A definition of "new drain," as used in earrying out these and other Acts, on parallel lines to that of a "new building" in the London Building Act and other Acts is also required.

As to Paring and Drainage of Stables. - It was suggested that power should be given to sanitary authorities to enable them to make a proper and definite bye-law for securing the proper paving and drainage of stables. The omission of the provisory half of the existing model bye-law for London relating to the paving of the floor of premises where horses and cattle are kept would perhaps meet the case. The proviso compels the sanitary authority to prove a nuisance in each case, and throws them back on to the

\footnotetext{
* Presidential Address read October, $1898 . \quad \dagger$ See vol. x., p. 363.
} 
nuisance section of the Public Health (London) Act, 1891, so that the present bye-law is for practical purposes of little use.

The Storage and Removal of Manure.-It was pointed out that the remedy for the nuisances arising from peat, and some other kinds of litter, was to provide a single receptacle for storage and removal. These nuisances are caused mainly by the shifting of the fermenting litter from one receptacle to another, rather than by the transit of the removing receptacle. Upon reconsideration the suggested additional provision to the bye-laws of the London County Council as to receptacles for dung appeared to me somewhat lengthy and complex. It would perhaps be better that the bye-law should provide that all receptacles for dung mixed with stable litter, other than straw, should be so constructed and used that the whole of the contents, in and together with the receptacle, could be removed without disturbance.

There are still other subjects for us to profitably consider.

As to Open Spaces about Buildings in London erected previous to 1895.-By Section 41 (2) of the London Building Act, 1894, the open space to be provided to a building may be entirely covered in up to a level of 16 feet above the adjoining pavement. In other words, no open space need be provided to the lower floors, viz., basement, ground, and possibly entresol, except in the case of artisans' dwellings. In consequence of this, old houses are being rebuilt in such a manner as to leave no sufficient opening for the purpose of allowing the drainage to discharge in the open, and thus the bye-laws of the London County Council and the sanitary authorities, devised to secure the exclusion of drain-openings from the interior of buildings, especially domestic buildings, are rendered useless. Some remedy is obviously necessary for this growing evil, and to prevent the extension of buildings over existing drain-openings.

Slaughter-houses. - The London County Council is at the present moment considering the establishment of public slaughter-houses. One strong reason urged by butchers against the introduction of the public slaughter-houses is the great expense entailed in carrying dead meat from the slaughter-house to their shops. It is difficult to understand why butchers who have private slaughter-houses should be allowed to claim the privilege of walking animals to their private slaughter-houses to the danger of the public. Surely this is not a privilege which should be attached to the use of a private slaughterhouse. In a crowded city like London the driving of live cattle through the streets ought not to be permitted. If it be a saving to the butcher, it is at the expense and inconvenience of the public; it is even more-it is a dangerous and inhuman practice. There 
cannot be the least hesitation in saying that the London County Council would be well advised to prohibit the practice of driving cattle through the streets. Then, when all butchers are upon a competitive equality as to the carriage of their meat, the solution of the slaughter-house question will be much facilitated.

Food Inspection.-Another question now ripe for consideration is that of the power to deal with food, contaminated, infected or polluted, so as not to be visibly unsound and yet dangerous to health. Under the Food and Drugs Acts these can be dealt with if the unsound food happens to enter into a mixture, but not when unmixed. For instance, under these Acts, anyone can be prosecuted successfully for selling sour milk mixed with ice-cream, but not for selling sour milk alone. Under the Public Health Act, 1875 , food can be seized if it is visibly unsound at the time of seizure, but there are a number of conditions of food dangerous to health which are not visible, and can only be determined by experimental examination. Of such foods, tuberculous milk is perhaps the best-known example.

In the Metropolis we have further powers under Section 47 (3) of the Public Health (London) Act, 1891, by which it is provided that when food has been purchased for the food of man, and it can be proved that it was unfit at the time of purchase, the vendor may be prosecuted although the food has not been previously seized and condemned. The procedure of a London authority under this section would appear to be, firstly, to find in the possession of any person any article of food purchased by him from another person for the food of man, whether for consumption or for re-sale, that is diseased, or unsound, or unwholesome, or unfit for the food of man; and, secondly, to prove that it was in such condition when purchased by the person in whose possession it was found. It would therefore appear within the power of a London authority to cause samples of food to be subjected to bacteriological examination, and if found diseased, etc., to prosecute the vendor. I am therefore about to recommend my authority to sanction the purchase of samples of food, and the submission of such samples to bacteriological examination, with a view to taking action under this subsection if necessary. It is obvious that in the case of tuberculosis, if such action were generally taken, a strong inducement would be felt by dairy-farmers to have their cows tested by tuberculin, a method of persuasion that appears to have escaped the notice of the Royal Commission on Tubereulosis.

Food Inspectors.-While upon the question of food, we may well consider the desirability of securing the appointment, for the pur- 
poses of food inspection, of men who have had some training specially fitting them for this kind of work. It must be confessed that the knowledge usually obtained by a sanitary inspector with reference to food is insufficient. There is reason to believe that no very great increase of salary over that of a well-paid sanitary inspector would tempt young veterinarians to enter this service, and undertake the inspection of cattle and food, put in force the Food and Drugs Acts, and undertake any other duties connected with food. If they did good work, their prospects would no doubt improve in proportion to the increased value at which the public estimated their services. Such officers, whether veterinarians or not, would clearly have to act under the instruction of, and in conjunction with medical officers of health, as, after all, their duties would be, not for the purpose of furthering agriculture, but of preventing the spread of disease amongst human beings.

Standard of Overerowding.- It seems a somewhat futile course for a sanitary authority to dishouse, under the Housing of the Working Classes Act, 1890, the population in a erowded area (where the persons occupy probably 300 cubic feet per head), and to erect dwellings ostensibly for the purpose of allowing them 600 cubic feet per head, when it is impossible to insist on their occupying nothing less than that amount. There is nothing to lead us to suppose that the new buildings erected under rehousing schemes will not, at any rate in the Metropolis, become as crowded as the buildings they replace. It has been said that overcrowding can be prevented by registering houses under the bye-laws "for houses let in lodgings to members of more than one family." When, however, we come to consider that nearly one half of the whole population of this country-according to the last census returnslive in tenements of one, two, three, or four rooms, the very class of dwelling for which these bye-laws are intended, we at once see how impracticable registration would be for the purpose of obtaining a standard of cubic space. There is a precedent in the Factory and Workshop Acts for the definition of cubic space in workplaces, viz., 250 cubic feet during ordinary hours, and 400 cubic feet during overtime, and we also want a definition of overcrowding for the purpose of controlling the occupation of dwelling-rooms. It is a mistake to have two standard allowances of space, the one for sleeping rooms, and the other for living and sleeping rooms, on account of the impossibility of regulating the usage of such rooms. The standard should, therefore, apply to all rooms used for sleeping, and the very minimum for that purpose should be 400 cubic feet. Much as we may long for more in the interests of the health of 
the poor, it is to be feared that it would not be practicable to provide it. This Society would do well to petition Parliament to enact a statutory definition of overcrowding at the very minimum of 400 cubic feet for adults and half that amount for children under ten, and a niggardly allowance even then, but one bright with the hope of some little improvement.

Vermin.-This Society might well urge the Legislature to class vermin of furniture, clothing, or place, as a nuisance under the Public Health Acts. It is probable that such a step would do even more good than the Cleansing of Persons Act. It is to be hoped that the words "infection" and "disinfection" will not be used in dealing with furniture, places, and things infested with or disinfested from vermin.

Bacteriological Laboratories for London.-The London County Council has recently proposed to apply to Parliament for powers to establish a bacteriological laboratory, and appoint an expert or experts in connection therewith, or otherwise to make arrangements whereby medical officers of health and medical practitioners may obtain the examination by a competent bacteriologist of material from suspected cases of infectious disease, with a view to aiding in the diagnosis. That the London County Council should be equipped with proper chemical, bacteriological, and other laboratories to carry on its work can scarcely be gainsaid, and indeed at the present moment it does actually carry on some chemical, bacteriological, and cognate work. Personally, I should be the last to raise any objection to the provision of public laboratories by the London County Council, but when it is proposed to apply for Parliamentary powers to arrange for the use of such a laboratory for the particular purpose proposed, it is permissible to show reasons for grave doubts as to the wisdom of such a course. It will be within your recollection that the Metropolitan Asylums Board some year or more ago, when the diphtheria beds in the hospitals were full, asked medical officers of health to distribute antitoxin for the use of diphtheria patients who could not be admitted, and to give full particulars as to the sanitary surroundings of such patients, so as to enable the Board to select which cases should be admitted. It will also be in your recollection that I pointed out at the time that that was not a proper course to pursue, and it is evident that bacteriological diagnosis should first decide between the admissible and nonadmissible cases. During 1897 the Board admitted into their hospitals no less than 643 cases as diphtheria that were found out not to be suffering from that disease, and 293 cases as enteric fever that were also found not to be so suffering. This appears to me to 
be a very serious matter, seeing that there are recognised means at hand for preventing or minimizing such dangerous risks in the Board's hospitals. These means would also enable the Board to exclude mistaken cases in time of pressure and leave more room for genuine cases. Further, the Asylums Board pays the sanitary authorities for all cases of dangerous infectious disease certified, and it may be a question, as bacteriological processes become more perfected, whether certificates of diphtheria and enteric fever may not depend more and more upon corroboration by bacteriological diagnosis. Those London authorities which have adopted such a system of diagnosis find it to work smoothly and well at the present moment, and if there is anything to be gained in controlling the notification and isolation of infectious disease by centralization, the Board that already deals with these matters would appear to facilitate this most. It is sufficient to picture the pitiful position of unfortunate medical officers of health compelled to carry on duplicate communications and correspondence with two public bodies over cases of diphtheria and enteric fever.

New Infectrous Disease Hospitals.-New hospitals have been opened during October at Brighton and Huddersfield. At the former town the new buildings are to replace the wood and iron structures erected in 1881 on the occasion of an outbreak of small-pox. The Corporation have had the matter of providing new hospital accommodation before them since 1892, the interval being occupied in meeting the objections of the Local Government Board, and in securing the free use of the site. The new accommodation includes an administrative block, ward for twenty beds, isolation and discharge blocks, disinfecting station, and porter's lodge. There is ample space on the site for future extension. The descriptive pamphlet shows that the new buildings have been designed both for artistic effect and effciency, and that they include all the latest developments of hospital construction, etc. One of the old blocks has been retained for present use, but we understand that the extension of the new buildings will be undertaken almost immediately. The hospital at Huddersfield is situated some two miles outside the town. The site was purchased in 1888, and has been the cause of long and frequent debate in the Council. It was not until 1894 that the competitive designs for the new hospital were obtained and the debate on the site closed. The new hospital will provide at once accommodation for ninety cases, with space for two additional wards of thirty beds each. The old Birkby Hospital and the existing small-pox hospital will be retained, the total existing accommodation for the town being 190 beds. The hospital bears evidence of careful planning, and appears to be up to date in every particular. The various blocks are connected by covered ways with dwarf side-walls, an addition which always appears to us to be most desirable, but one which, we believe, the Local Government Board does not regard favourably. 